\title{
The life cycle of Paracardicoloides yamagutii Martin, 1974 (Digenea: Sanguinicolidae)
}

\author{
Matthew J. Nolan ${ }^{1,2}$ and Thomas H. Cribb ${ }^{1,2}$ \\ ${ }^{1}$ Department of Microbiology and Parasitology and the ${ }^{2}$ Centre for Marine Studies, The University of Queensland, Brisbane, \\ Queensland 4072, Australia
}

Key words: Paracardicoloides yamagutii, Sanguinicolidae, Anguilla reinhardtii, Anguillidae, Posticobia brazieri, Hydrobiidae, ITS2 rDNA

\begin{abstract}
The sanguinicolids Paracardicoloides yamagutii Martin, 1974 and Plethorchis acanthus Martin, 1975 were obtained from their definitive hosts, Anguilla reinhardtii Steindachner and Mugil cephalus Linnaeus (respectively) in the tributaries of the Brisbane River, Queensland, Australia. Two putative sanguinicolid cercariae were collected from a hydrobiid gastropod, Posticobia brazieri Smith, in the same waters. The two cercariae differ markedly in size and the form of their sporocysts. Both putative cercariae develop in the digestive gland of Po. brazieri. The ITS2 rDNA region from these sanguinicolids and a Clinostomum species (utilised as an outgroup due to the close morphological similarities between the cercarial stages of the Clinostomidae and the Sanguinicolidae) were sequenced and aligned. Comparison of the ITS2 sequences showed one cercaria to be that of $P$. yamagutii. This is the first sanguinicolid life history determined by a molecular method. $P$. yamagutii is the fourth sanguinicolid known to utilise a freshwater hydrobiid gastropod as its intermediate host. ITS2 rDNA is effective in distinguishing sanguinicolids at the species level.
\end{abstract}

Sanguinicolid blood flukes are parasites of marine and freshwater fishes (Smith 1972, 1997). Most species establish in the heart, bulbus arteriosus, ventral aorta, or branchial vessels, although distributions within the cephalic and dorsal vessels are not uncommon (Kirk and Lewis 1994). Few species have been studied in detail and only 11 life cycles have been demonstrated experimentally (Smith 1997). The first life cycle determined was that for Sanguinicola inermis Plehn, 1905 by Scheuring (1922).

The life cycle of a sanguinicolid follows a basic digenean two-host strategy and the definitive host is infected by direct penetration of cercariae (Kirk and Lewis 1992). Identification of sanguinicolid intramolluscan stages using morphological characters alone is difficult given the lack of distinguishing features. Therefore, the most common form of life cycle determination is by the partial, or complete, demonstration of the life cycle in a laboratory (e.g. Meade and Pratt 1965). Although this manipulative approach allows for a complete understanding of all stages of the interaction, these methods are time consuming and not always feasible (Jousson et al. 1998).

As an alternative to the classical method of life cycle determination, molecular tools in the form of DNA sequence data allow detection of genetic variation between morphologically similar species and identification of morphologically distinct stages in a digenean life cycle (Jousson and Bartoli 2000). A few studies (Cribb et al. 1998, Jousson et al. 1998, Anderson 1999, Jousson et al. 1999, Bartoli et al. 2000, Jousson and Bartoli
2000, Overstreet et al. 2002) have used ITS rDNA regions for the elucidation of digenean life cycles.

Martin (1974) described Paracardicoloides yamagutii Martin, 1974 from the Australian long-finned eel, Anguilla reinhardtii Steindachner, 1867, from the Brisbane River and its associated tributaries. Martin (1975) postulated that the cercarial stages of $P$. yamagutii and Plethorchis acanthus Martin, 1975, another sanguinicolid from Mugil cephalus Linnaeus, 1758, might be found in the hydrobiid gastropod Posticobia brazieri Smith, 1882. In this study $P$. yamagutii and $P l$. acanthus were obtained from their definitive and putative molluscan hosts and their ITS2 rDNA region was sequenced and aligned in order to elucidate their life cycles.

\section{MATERIALS AND METHODS}

Eels (Anguilla reinhardtii) and mullet (Mugil cephalus) were collected from sites in and around Brisbane using baited lines, seine netting, and by backpack electrofishing (SmithRoot 12B Backpack Electrofisher). The heart, gills and visceral mesenteries of $A$. reinhardtii were examined for adult $P$. yamagutii; the visceral mesenteries of $M$. cephalus were examined for adult and egg stages of $\mathrm{Pl}$. acanthus. Specimens intended for morphological examination were heat fixed in $0.85 \%$ saline and stored in $10 \%$ formaldehyde (room temperature). Worms intended as sources of DNA were preserved in $100 \%$ ethanol.

Snails (Po. brazieri) were collected using a hand net. Snails were plated out in haemagglutination trays in aged water and left for 1 to 7 days to allow for natural cercarial emergence. Infected snails could be kept for extended periods to allow for 
continual cercarial emergence or dissected to obtain sporocysts from host tissue. Cercariae and sporocysts intended for morphological examination were heat fixed in $0.85 \%$ saline and placed in $10 \%$ formaldehyde. Cercariae for DNA analysis were preserved in $100 \%$ ethanol.

Morphological specimens were stained in Mayer's haematoxylin, destained in $1 \%$ hydrochloric acid, and neutralised in a $0.5 \%$ ammonium hydroxide solution. Stained specimens were dehydrated in a graded series of alcohols, cleared in oil of cedarwood and mounted in Canada balsam. Measurements (in $\mu \mathrm{m}$ ) were made with the aid of an ocular micrometer and are presented as a range followed by the mean in parentheses. Drawings were completed using a drawing tube. External and some internal cercarial features were drawn freehand from live cercariae.

Cercariae for scanning electron microscopy (SEM) were washed three times in a $0.1 \mathrm{M}$ cacodylate buffer solution. Post-fixation was achieved in $0.1 \mathrm{M}$ cacodylate buffered osmium tetroxide $(1.0 \%)$. Post-fixed specimens were washed in water, dehydrated in a graded series of alcohols (50-60-70-80 $90-100-100 \%$ for 10 minutes apiece), and placed in hexamethyl disilazane (HMDS) for 30 minutes ( 2 times in a 100\% solution). Specimens were left overnight in HMDS to dry, before being sputter coated with gold. Observations were made with a JEOL 6300F scanning electron microscope operated at $10 \mathrm{kV}$

Four sanguinicolids, including two tentative sanguinicolid cercariae, and a Clinostomum species were collected for sequencing (Table 1). The Clinostomum species was included as an outgroup in this study as a consequence of the close morphological association between the cercarial stages of the Clinostomidae and the Sanguinicolidae. DNA was extracted from ethanol-hardened specimens using a phenol-chloroform method (Sambrook et al. 1989). The ITS2 rDNA region was amplified by PCR using the forward primers " $3 \mathrm{~s}$ " (5'-GGT ACC GGT GGA TCA CGT GGC TAG TG-3') (middle of 5.8S rDNA) (Bowles et al. 1993) or "GA1" (5'-AGA ACA TCG ACA TCT TGA AC-3') (3' end of 5.8S rDNA) (Anderson and Barker 1998) and the reverse primer "ITS2.2" (5'CCT GGT TAG TTT CTT TTC CTC CGC-3') (5' end of 28S rDNA) (Cribb et al. 1998). PCR cycle sequencing reactions were performed in $20 \mu \mathrm{l}$ volumes containing $1.6 \mu \mathrm{l}$ of $\mathrm{MgCl}_{2}$ $(25 \mathrm{mM}), 2 \mu \mathrm{l}$ of PCR reaction buffer (PROMEGA) $(10 \times), 0.8$ $\mu \mathrm{l}$ of dNTPs $(5 \mathrm{mM}), 0.75 \mu \mathrm{l}$ of primer (both forward and reverse) $(10 \mathrm{pmol}), 0.25 \mu \mathrm{l}$ of Taq polymerase (PROMEGA) ( 5 units $/ \mu \mathrm{l}$ ), $2 \mu \mathrm{l}$ of DNA template $(5-100 \mathrm{ng}$ ), made up to 20 $\mu 1$ with Ro water and run on either a Minicycler (MJ Research, supplied by Bresatec) or an FTS-320 Thermal Cycler with the cycling protocol consisting of: $95^{\circ} \mathrm{C}$ for $3 \mathrm{~min}, 45^{\circ} \mathrm{C}$ for 2 $\min , 72^{\circ} \mathrm{C}$ for $90 \mathrm{sec}$ for $1 \mathrm{cycle} ; 95^{\circ} \mathrm{C}$ for $45 \mathrm{sec}, 50^{\circ} \mathrm{C}$ for 45 sec, $72^{\circ} \mathrm{C}$ for $90 \mathrm{sec}$ for 4 cycles; $95^{\circ} \mathrm{C}$ for $20 \mathrm{sec}, 52^{\circ} \mathrm{C}$ for 20 sec, $72^{\circ} \mathrm{C}$ for $90 \mathrm{sec}$ for 30 cycles; and a final extension at $72^{\circ} \mathrm{C}$ for $5 \mathrm{~min}$. Purification of PCR products prior to sequencing was completed using a QIAquick PCR Purification Kit (Qiagen) according to manufacturer's instructions. PCR products were sequenced using an ABI Prism BigDye Terminator Cycle Sequencing Ready Reaction Kit (version 3.1) according to manufacturers instructions. Each PCR product was sequenced in both directions.

Consensus sequences were assembled in Sequencher (Version 3.1.1 for Macintosh. 1991-1998 Gene Codes Corporation), aligned by eye and analysed with PAUP $4.0 \mathrm{~b} 8$ (PPC) (Swofford 1998).

Voucher specimens for both Paracardicoloides yamagutii ( 2 adults) and Plethorchis acanthus (2 adults) have been deposited in the Queensland Museum, Australia, nos. QM G 222650-222651 and QM G 222648-222649, respectively, as well as in the Institute of Parasitology, Academy of Sciences of the Czech Republic, České Budějovice: P. yamagutii (1 adult) and $P l$. acanthus (1 adult), nos. D-499 and D-501, respectively.

\section{RESULTS}

\section{Molecular results}

PCR amplification and subsequent sequencing of ITS2 rDNA of samples gave single products varying in size from $260 \mathrm{bp}$ (Clinostomum sp.) to $414 \mathrm{bp}$ (Pl. acanthus). Base composition was thymine biased among all samples, with an overall GC content of $48.1 \%$ for the Clinostomum sp., $42.4 \%$ for P. yamagutii, $33.6 \%$ for $P l$. acanthus, $42.4 \%$ for Cercaria "Type A" and $43.6 \%$ for Cercaria "Type B". There were no base pair differences between the sequences of samples of Cercaria "Type A" (four replicates) and those of $P$. yamagutii (five replicates). The sequences of Cercaria "Type B" (nine replicates) and $P l$. acanthus (13 replicates) did not agree with any other ITS2 sequence. There were no base pair differences between the replicate sequences of either Cercaria "Type B" or Pl. acanthus.

Table 1. List of sanguinicolid species whose ITS2 rDNA region was sequenced, the host species, the size of the ITS2 gene, accession number and locality from which collected.

\begin{tabular}{|c|c|c|c|c|}
\hline Species examined & Host (Family) & Size (bp) & Accession Nos. & Locality \\
\hline $\begin{array}{l}\text { Clinostomidae } \\
\text { Clinostomum sp. } \\
\text { Sanguinicolidae }\end{array}$ & Hypseleotris galii (Eleotridae) & 29 & 5871 & Moggill Creek, QLD, Australia \\
\hline Paracardicoloides yamagutii & Anguilla reinhardtii (Anguillidae) & 34 & AY4 & ${ }^{3}$, QLD, Australia \\
\hline Plethorchis acanthus & Mugil cephalus (Mugilidae) & 41 & 75 & Heron Island, QLD, Australia \\
\hline Cercaria "Type A" & Posticobia brazieri (Hydrobiidae) & 344 & AY465869 & $\mathrm{DFC}^{1}, \mathrm{PPC}^{2}, \mathrm{QLD}$, Australia \\
\hline Cercaria "Type B" & Posticobia brazieri (Hydrobiidae) & 351 & AY465870 & $\mathrm{DFC}^{1}, \mathrm{MC}^{4}, \mathrm{QLD}$, Australia \\
\hline
\end{tabular}

${ }^{1}$ Downfall Creek, Virginia, QLD; ${ }^{2}$ Pullen Pullen Creek, Pullenvale, QLD; ${ }^{3}$ Church Bank Weir Reserve, Ipswich QLD; and ${ }^{4}$ Moggill Creek, Brookfield, QLD 
S a n g u in i c o li d a e von Graff, 1907

\section{Paracardicoloides yamagutii Martin, 1974}

Remarks. Our new specimens agreed well with the original description given by Martin (1974) with the exception of the form of the uterus. Martin (1974) stated that the uterus forms a coiled tube. In contrast, the present study found the uterus takes the form of an inverted U (Fig. 1).

$\mathrm{M}$ a t e r i a 1 e x a m i n e d : ex Anguilla reinhardtii, Moggill Creek (QLD), Mar. 2000, 1 specimen; ex A. reinhardtii, Downfall Creek, Virginia (QLD), Jun. 2000, 2 specimens; ex A. reinhardtii, Warrill Creek (QLD), Aug. 2000, Nov. 2001, Dec. 2001, 15 specimens.

R e c or d s : 1. (Martin 1974), 2. Present study.

S i te i n hos t: Dorsal aorta (1), atrium (2), ventricle (2), gills (2), blood vessels of intestine (2), blood vessels of swim bladder (2), blood vessels of kidneys (2).

H o s t : Anguilla reinhardtii Steindachner, 1867 (Anguilliformes: Anguillidae) $(1,2)$.

L o c a 1 i t i e s : Downfall Creek, Virginia $\left(27^{\circ} 22^{\prime} \mathrm{S}\right.$, $\left.153^{\circ} 03^{\prime} \mathrm{E}\right)$, Moggill Creek, Brookfield (2729'S,

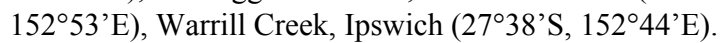

$\mathrm{Prevalence}$ of i n fect i o n: One of three $A$. reinhardtii (33\%) from Downfall Creek infected with 2 specimens; one of two A. reinhardtii (50\%) from Moggill Creek infected with 1 specimen; four of five $A$. reinhardtii (80\%) from Warrill Creek infected with 15 specimens.

\section{Intra-molluscan stages}

A total of 11,314 Po. brazieri were examined from five tributaries of the Brisbane River. Two previously undescribed sanguinicolid-type cercariae were found. The two species differ dramatically in their sizes and are referred to here as "Type A" (large) and "Type B" (small). Four "Type A" cercarial infections (prevalence $0.04 \%$ ), and 76 "Type B" cercarial infections (prevalence $0.67 \%$ ) were found.

\section{Cercaria "Type A"}

Sporocyst (Fig. 2a). Measurements and descriptions based on six whole mounts. Sporocysts loose within substance of digestive gland of host, white and opaque. Body thick-walled, elongate, tubular, consistent width, however, may appear as beaded string, with great variation in both depth and length, 325-683 (457) × 59-107 (89), containing cercariae in various stages of development (Fig. 2a). Mature cercariae isolated in terminal beads and emerge terminally although no birth pore observed.

Cercaria (Figs. 2b, 4a-d). Description and measurements taken from 12 stained and numerous live specimens. Body 117-134 (125) long, 32-36 (33) deep, widest level with saccular gut, covered with spinose ridges (not evident in stained specimens) (Figs. 4a, 4c). Dorsal finfold present. Tail slender, straight, furcate, 196-209 (204) long, covered with short spines ventrally and dorsally (Fig. 4d). Furca 22-32 (27) long, furcal

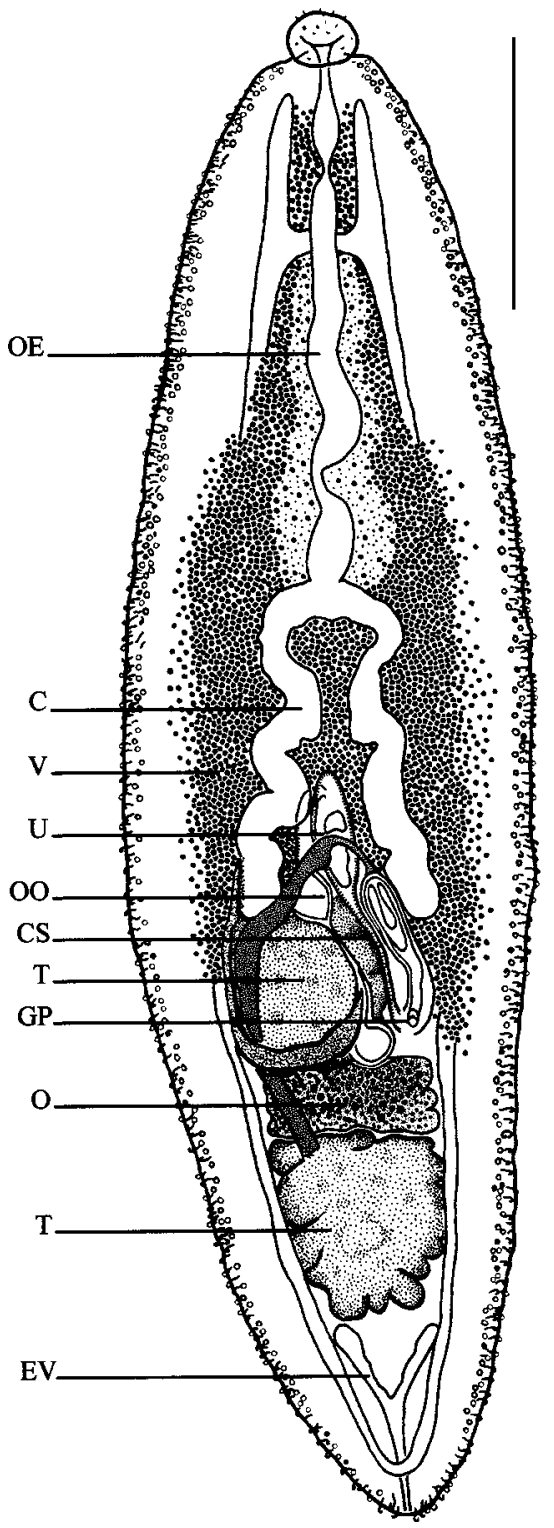

Fig. 1. Paracardicoloides yamagutii, adult. Ventral view, whole worm. Abbreviations: $\mathrm{C}$ - caeca; $\mathrm{CS}$ - cirrus sac; EV excretory vesicle; GP - genital pore; O - ovary; OE - oesophagus; OO - oötype; $\mathrm{T}$ - testis; $\mathrm{U}$ - uterus; V - vitellarium. Scale bar $=200 \mu \mathrm{m}$.

finfolds present, not observed on stained specimens. Apical papilla demarcated by slight body constriction, appears partitioned posteriorly by fine membrane anterior to first pair of penetration glands, bears 7-8 circlets of spines (Figs. 4a, 4b). Penetration glands, though not clearly visible, probably run dorsally in 5 pairs; no ducts seen leaving glands; vestiges of penetration ducts seen in anterior-most region of body. Mouth ventro-subterminal. Intestine sinuous, ends in thick-walled chamber before entering saccular gut (Fig. 2b). Genital primordium heavily staining, medial, 16-23 (19) deep. Excretory vesicle sac-like, posterior to genital primordium, 
Nolan, Cribb: The life cycle of Paracardicoloides yamagutii
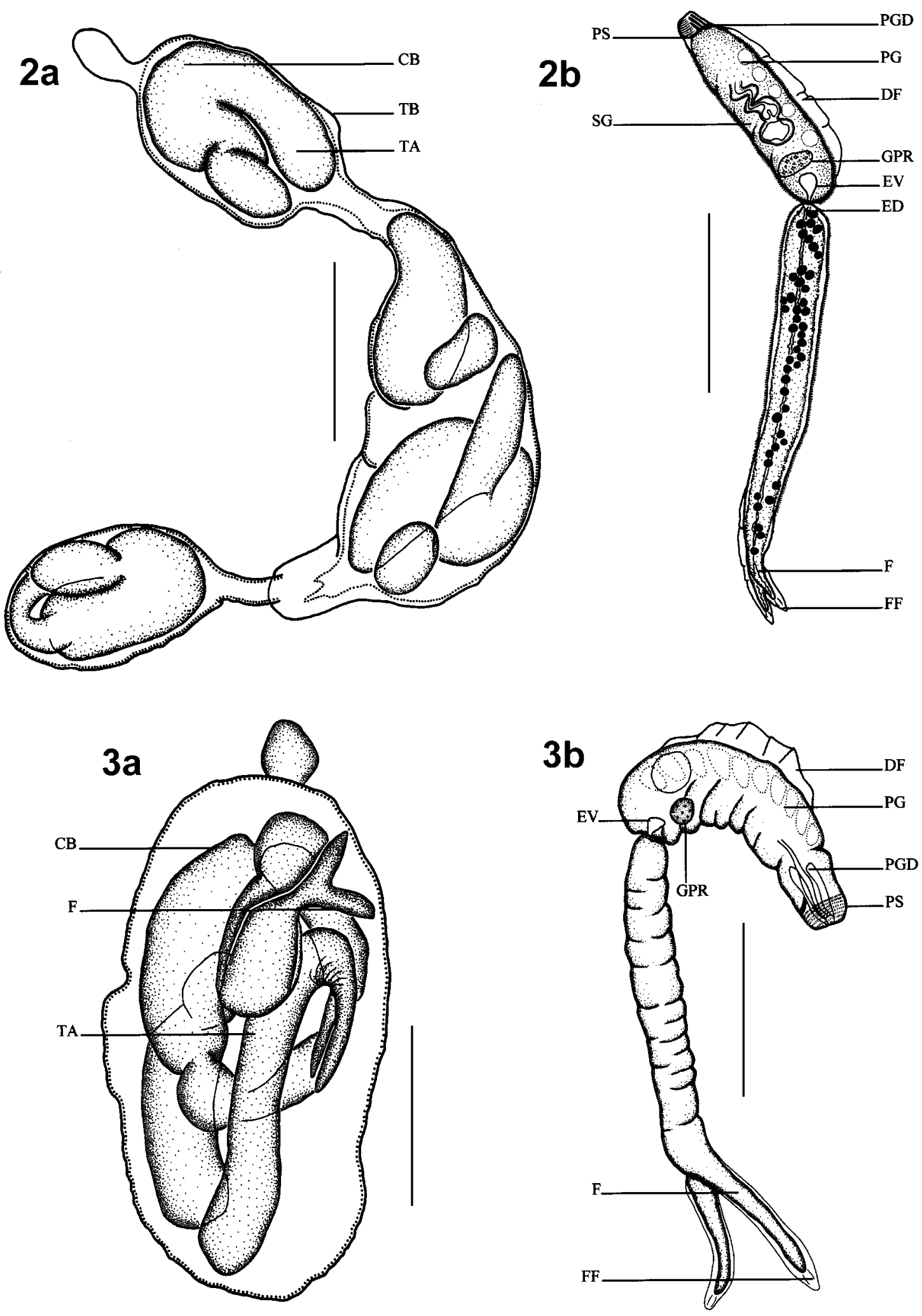

Figs. 2, 3. Paracardicoloides yamagutii. Fig. 2. a - Sporocyst "Type A", lateral view; b-Cercaria "Type A", lateral view. Fig. 3. a - Sporocyst "Type B", dorso-ventral view; b-Cercaria "Type B", lateral view. Abbreviations: CB - cercarial body; DF - dorsal finfold; ED - excretory duct; EV - excretory vesicle; F - furcae; FF - furcal finfold; GPR - genital primordium; PG - penetration glands; PGD - penetration gland duct; PS - penetration spines; SG - saccular gut; TA - tail; TB - terminal bead. Some cercarial structures drawn from live specimens, hence there are inaccuracies in the orientation and size of some structures. Scale bars: Figs. $2 \mathrm{a}, 2 \mathrm{~b}=100 \mu \mathrm{m}$; Figs. 3a, $3 \mathrm{~b}=50 \mu \mathrm{m}$. 
connected by duct to junction of tail and body. Single duct runs length tail from excretory vesicle, dividing at furcae to exit at tips. Nuclei run entire length of tail stem.

H o s t: Posticobia brazieri Smith, 1882 (Gastropoda: Hydrobiidae).

Site of infection: Digestive gland.

Materia 1 ex a m in ed: ex Po. brazieri, Downfall Creek (QLD), Mar. 2000, Jun. 2000, live and fixed specimens; ex Po. brazieri, Wivenhoe Pocket (QLD), May 2001, 8 specimens.

L o c a 1 i t i e s : Downfall Creek, Virginia $\left(27^{\circ} 22^{\prime}\right.$ 'S, $\left.153^{\circ} 03^{\prime} \mathrm{E}\right)$, Pullen Pullen Creek, Pullenvale (273'ㅇ, $\left.152^{\circ} 52^{\prime} \mathrm{E}\right)$, and Wivenhoe Pocket, Brisbane River (27 $25^{\circ}$ S, $\left.152^{\circ} 37^{\prime} \mathrm{E}\right)$, South East Queensland, Australia.

De p os ition of $\mathrm{spec}$ i m e n s: 6 sporocyst and 8 cercarial specimens in the Queensland Museum, Australia, nos. QM G 222652-222658 (slides); additional specimens ( 2 sporocysts and 6 cercariae) in the Institute of Parasitology, Academy of Sciences of the Czech Republic, České Budějovice (no. D-500).

\section{Cercaria "Type B"}

Sporocyst (Fig. 3a). Description and measurements based on 12 whole mounts. Sporocysts white, thinwalled, found in tight aggregations within digestive gland of host, ovoid to spherical, though usually longer than wide, 70-130 (100) long, 44-114 (71) wide (Fig. $3 a)$. Sporocysts contain more than four cercariae at varying stages of development. No birth pore observed in live or stained specimens. Mature cercariae emerge from terminal region of sporocyst.

Cercaria (Fig. 3b). Description and measurements from 10 stained specimens and numerous live specimens. Cercarial body in life with marked ventral curvature, especially in resting position, small, cylindrical, slender, 65-81 (74) long, deepest at genital primordium, 16-21 (20) (Fig. 3b). Dorsal finfold of varying length and height. Tail straight, slender, furcate, 91-130 (113) long. Furcae possess fine finfolds, not seen on stained specimens, 22-32 (28) long. Apical papilla delimited posteriorly by membrane, with body constriction anterior to penetration glands, 13-20 (17) long, 13-20 (14) wide, bears 7-8 circlets of spines. Penetration glands (appearing as spaces) probably run dorsally in 5 pairs. No ducts seen extending from glands. Mouth ventrosubterminal. Genital primordium distinct under low magnification, situated anterior to excretory vesicle, and 4.8-8.1 (6.1) deep. Excretory vesicle, at junction of body and tail, circular, ventral, pulsates rhythmically. No other excretory organs visible in either stained or live specimens.

H o s t : Posticobia brazieri Smith, 1882 (Gastropoda: Hydrobiidae).

Site of infection: Digestive gland.

Material ex a min ed: ex Po. brazieri, Downfall Creek (QLD), Mar. 2000, Apr. 2000, Jun. 2000, Jul. 2000, numerous live and fixed specimens.
L o c a 1 i t i e s : Downfall Creek, Virginia (27 $22^{\prime}$ 'S, $\left.153^{\circ} 03^{\prime} \mathrm{E}\right)$, Moggill Creek, Brookfield (27 $\left.29^{\circ} \mathrm{S}, 152^{\circ} 53^{\prime} \mathrm{E}\right)$;

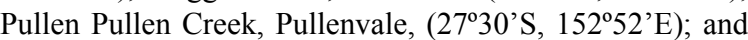

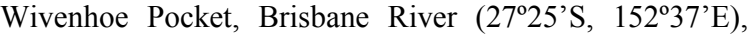
South East Queensland, Australia.

De p os ition of $\mathrm{spec}$ i m e n s : 14 sporocyst and 7 cercarial specimens in the Queensland Museum, Australia, nos. QM G 222659-222666 (slides); additional specimens (3 sporocysts and 8 cercariae) in the Institute of Parasitology, Academy of Sciences of the Czech Republic, České Budějovice (no. D-502).

\section{DISCUSSION}

The ITS2 sequences of Paracardicoloides yamagutii and Plethorchis acanthus were sufficiently different that alignment was difficult. The sequences were a mosaic of relatively short conserved regions separated by large insertions and highly variable regions. Morgan and Blair (1998) identified only two conserved strings in their alignment involving 4 orders and 42 species of trematodes. They concluded that the Strigeiformes (including the blood fluke families Sanguinicolidae, Schistosomatidae and Spirorchiidae) display a high level of differentiation when compared to other orders. As a consequence, they suggested that the Strigeiformes are either an old lineage or one that has undergone rapid divergence.

Comparison of the ITS2 sequences of Cercaria "Type A" to those of $P$. yamagutii revealed no base pair differences. Many studies have shown ITS2 to be effective in distinguishing species of digeneans (Adlard et al. 1993, Morgan and Blair 1995, Anderson and Barker 1998, Cribb et al. 1998, Jousson et al. 1999). A few cases are known where well-accepted species have been shown to have identical ITS2 sequences (Despres et al. 1992, Niewiadomska and Laskowski 2002). In the present study there is no evidence to suggest that more than one species has this sequence. Therefore, we conclude that Cercaria "Type A" is that of P. yamagutii. There was no sequence variation between replicate sequences from different geographical regions for all species suggesting that intraspecific variation may not exist in the ITS2 rDNA region of sanguinicolids.

Phylogenetic relationships inferred for the sanguinicolids in this study (not figured) show that although Cercaria "Type B" does not belong to P. yamagutii or $P l$. acanthus it does appear to be a sanguinicolid cercaria. Although Cercaria "Type B" has typical sanguinicolid morphology (dorsal finfold, furcate tail and furcal finfolds), cercariae of the Clinostomidae, the sister group to the Sanguinicolidae, also possess similar morphological characters (Agarwal 1959, Dönges 1974, Yamaguti 1975, Lo et al. 1982). The apparent close morphological association between cercarial stages from different, but closely related, families was the basis for including the Clinostomum $\mathrm{sp}$. in the analysis.

The intermediate host of $P$. yamagutii is the freshwater hydrobiid gastropod Posticobia brazieri. Hine 

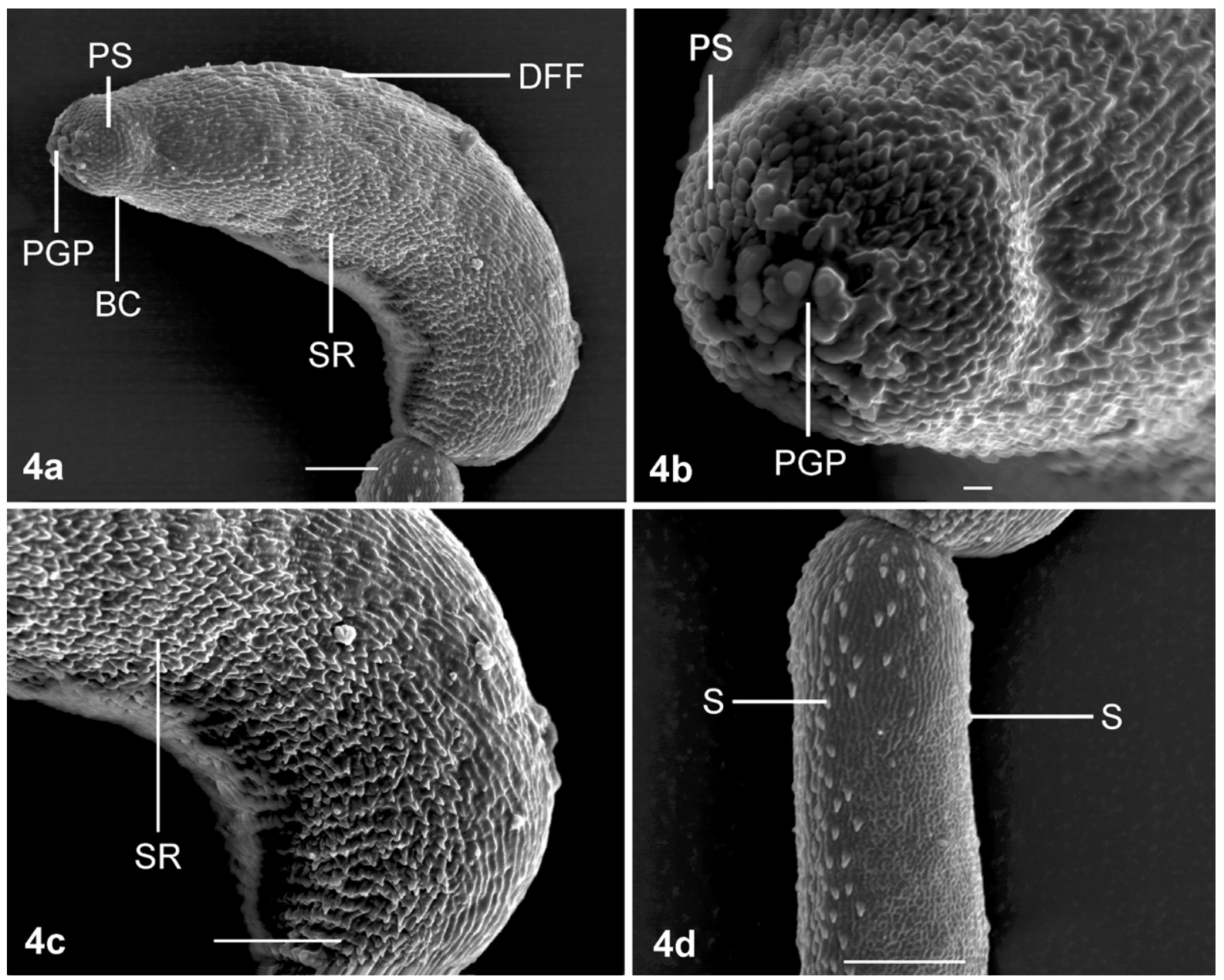

Figs. 4a-d. Paracardicoloides yamagutii, cercaria; scanning electron micrographs. Abbreviations: BC - body constriction; DFF - dorsal finfold; PGP - penetration gland duct pore; PS - penetration spines; S - spines; SR - spinose ridges. Scale bars: Figs. 4a, $4 \mathrm{c}, 4 \mathrm{~d}=10 \mu \mathrm{m} ;$ Fig. $4 \mathrm{~b}=1 \mu \mathrm{m}$.

(1978) predicted that the intermediate host of this species in New Zealand might be another hydrobiid, Potamopyrgus antipodarum Gray, 1843 (also known as P. jenkinsi Smith, 1889). The distribution of Po. brazieri is restricted to Australia (Smith 1992) suggesting that another species must act as the intermediate host for P. yamagutii in New Zealand. Species from the Hydrobiidae (Fluminicola fusca, F. seminalis, Oxytrema circumlineata, and $O$. silicula) act as intermediate hosts to three species of Sanguinicola in North America (Sanguinicola klamathensis Wales, 1958, S. davisi Wales, 1958, and S. alseae Meade et Pratt, 1965) (Wales 1958, Meade and Pratt 1965, Meade 1967). A comparison of the Sanguinicola species with P. yamagutii reveals differences in all morphological characters (Wales 1958, Meade and Pratt 1965, Meade 1967, Martin 1974) except body shape and the presence of a cirrus sac. The cercaria of $P$. yamagutii differs from those of Sanguinicola alseae, $S$. davisi, and $S$. klamathensis in having penetration glands that run dorsally as opposed to filling the cercarial body, and a highly conspicuous genital primordium.

Cercaria "Type B" had a prevalence of infection of $0.67 \%$ within the gastropod Po. brazieri in this study, a prevalence relatively high when compared to that of the cercaria of $P$. yamagutii over the same period $(0.04 \%)$. Although the cercaria of $P$. yamagutii is rare, the adult is known and described (Martin 1974). Given the numbers of potential definitive hosts is restricted as a consequence of the biology of Po. brazieri, it is surprising that the same is not true for Cercaria "Type B". As Po. brazieri is a freshwater species, the definitive host of this cercaria is also likely to be a freshwater species.

Acknowledgements. We are grateful to: Dr. Anna Murrell, Miss Kathryn Hall and Mr. Feras Lafi for their assistance with the molecular component of this study, and Rick Webb of the Centre for Microscopy and Microanalysis, the University of Queensland, St Lucia campus for his assistance with scanning electron microscopy. 


\section{REFERENCES}

ADLARD R.D., BARKER S.C., BLAIR D., CRIBB T.H 1993: Comparisons of the second internal transcribed spacer (ribosomal DNA) from populations and species of Fasciolidae (Digenea). Int. J. Parasitol. 23: 423-425.

AGARWAL S.M. 1959: Studies on the morphology, systematics and life history of Clinostomum giganticum $\mathrm{n}$. $\mathrm{sp}$. (Trematoda: Clinostomidae). Indian J. Helminthol. 11: 75-115.

ANDERSON G.R. 1999: Identification and maturation of the metacercaria of Indodidymozoon pearsoni. J. Helminthol. 73: 21-26.

ANDERSON G.R., BARKER S.C. 1998: Inference of phylogeny and taxonomy within the Didymozoidae (Digenea) from the second internal transcribed spacer (ITS2) of ribosomal DNA. Syst. Parasitol. 41: 87-94.

BARTOLI P., JOUSSON O., RUSSELL P.F. 2000: The life cycle of Monorchis parvus (Digenea: Monorchiidae) demonstrated by developmental and molecular data. J. Parasitol. 86: 479-489.

BOWLES J., HOPE M., TIU W.U., LIU X., McMANUS D.P. 1993: Nuclear and mitochondrial genetic markers highly conserved between Chinese and Philippine Schistosoma japonicum. Acta Trop. 55: 217-229.

CRIBB T.H., ANDERSON G.R., ADLARD R.D., BRAY R.A. 1998: A DNA-based demonstration of a three-host life-cycle for the Bivesiculidae (Platyhelminthes: Digenea). Int. J. Parasitol. 28: 1791-1795.

DESPRES L., IMBERT-ESTABLET D., COMBES C., BONHOMME F. 1992: Molecular evidence linking hominid evolution to recent radiation of schistosomes (Platyhelminthes: Trematoda). Mol. Phylogenet. Evol. 1: 295-304.

DÖNGES J. 1974: The life cycle of Euclinostomum heterostomum (Rudolphi, 1809) (Trematoda: Clinostomidae). Int. J. Parasitol. 4: 79-90.

HINE P.M. 1978: Distribution of some parasites of freshwater eels in New Zealand. N. Z. J. Mar. Freshwater Res. 12: 179-187.

JOUSSON O., BARTOLI P. 2000: The life cycle of Opecoeloides columbellae (Pagenstecher, 1863) n. comb. (Digenea, Opecoelidae): evidence from molecules and morphology. Int. J. Parasitol. 30: 747-760.

JOUSSON O., BARTOLI P., PAWLOWSKI J. 1999: Molecular identification of developmental stages in Opecoelidae (Digenea). Int. J. Parasitol. 29: 1853-1858.

JOUSSON O., BARTOLI P., ZANINETTI L., PAWLOWSKI J. 1998: Use of the ITS rDNA for elucidation of some lifecycles of Mesometridae (Trematoda, Digenea). Int. J. Parasitol. 28: 1403-1411.

KIRK P.S., LEWIS J.W. 1992: The laboratory maintenance of Sanguinicola inermis Plehn, 1905 (Digenea: Sanguinicolidae). Parasitology 104: 121-127.

KIRK R.S., LEWIS J.W. 1994: Sanguinicoliasis in cyprinid fish in the UK. In: A.W. Pike and J.W. Lewis (Eds.), Parasitic Diseases of Fish. Samara Publishing, Wales, pp. 101117.

LO C.F., WANG C.-H., HUBER F., KOU G.-H. 1982: The study of Clinostomum complanatum (Rudolphi, 1814) II. The life cycle of Clinostomum complanatum. CAPD Fisheries Series, Fish Disease Research (IV) 8: 26-56.
MARTIN W.E. 1974: Paracardicoloides yamagutii gen. et sp. n. from an Australian eel (Trematoda: Sanguinicolidae). Proc. Helminthol. Soc. Wash. 41: 22-25.

MARTIN W.E. 1975: Plethorchis acanthus gen. et sp. n. (Trematoda: Sanguinicolidae) in mullet, Mugil cephalus L., from Queensland, Australia. Proc. Helminthol. Soc. Wash. 42: 79-82.

MEADE T.G. 1967: Life history studies on Cardicola klamathensis (Wales, 1958) Meade and Pratt, 1965 (Trematoda: Sanguinicolidae). Proc. Helminthol. Soc. Wash. 34: 210-212.

MEADE T.G., PRATT I. 1965: Description and life history of Cardicola alseae sp. n. (Trematoda: Sanguinicolidae). J. Parasitol. 51: 575-578.

MORGAN J.A.T., BLAIR D. 1995: Nuclear rDNA ITS sequence variation in the trematode genus Echinostoma: an aid to establishing relationships within the 37-collar-spine group. Parasitology 111: 609-615.

MORGAN J.A.T., BLAIR D. 1998: Trematode and monogenean rRNA ITS2 secondary structures support a fourdomain model. J. Mol. Evol. 47: 406-419.

NIEWIADOMSKA K., LASKOWSKI Z. 2002: Systematic relationships among six species of Diplostomum Nordmann, 1832 (Digenea) based on morphological and molecular data. Acta Parasitol. 47: 20-28.

OVERSTREET R.M., CURRAN S.S., POTE L.M., KING D.T., BLEND C.K., GRATER W.D. 2002: Bolbophorus damnificus n. sp. (Digenea: Bolbophoridae) from the channel catfish Ictalurus punctatus and American white pelican Pelecanus erythrorhynchos in the USA based on life-cycle and molecular data. Syst. Parasitol. 52: 81-96.

SAMBROOK J., FRITSCH E.F., MANIATIS T. 1989: Molecular Cloning: a Laboratory Manual. Cold Spring Harbor Laboratory Press, USA, Cold Spring Harbor, New York, pp. E3-E4.

SCHEURING L. 1922: Der Lebenszyklus von Sanguinicola inermis Plehn. Zool. Jahrb. Abt. Anat. Ontog. Tiere 44: 265-310.

SMITH B.J. 1992: Non-Marine Mollusca. Zoological Catalogue of Australia Series, Vol. 8. AGPS Press, Canberra, $405 \mathrm{pp}$.

SMITH J.W. 1972: The blood flukes (Digenea: Sanguinicolidae and Spirorchidae) of cold-blooded vertebrates and some comparisons with the schistosomes. Helminthol. Abstr., Series A, 41: 161-194.

SMITH J.W. 1997: The blood flukes (Digenea: Sanguinicolidae and Spirorchidae) of cold-blooded vertebrates: Part 1. A review of the literature published since 1971, and bibliography. Helminthol. Abstr. 66: 255-292.

SWOFFORD D.L. 1998: PAUP: Phylogenetic Analysis Using Parsimony (and other methods). Sinauer Associates, Sunderland, Massachusetts.

WALES J.H. 1958: Two new blood fluke parasites of trout. Calif. Fish Game 44: 125-136.

YAMAGUTI S. 1975: A Synoptical Review of Life Histories of Digenetic Trematodes of Vertebrates. Part 1. Keigaku Publishing Co., Tokyo, 809 pp. 